\title{
Geochemical Evaluation of Flowback and Produced Water from Five Hydraulically-Fractured Wells in the Niobrara Formation, Denver- Julesburg Basin, CO, USA: A 228 Day Field Study
}

\author{
DEREK CARO ${ }^{1}$, JOHN P. KASZUBA ${ }^{1}$ AND OLIVIA \\ TERRY $^{2}$ \\ ${ }^{1}$ University of Wyoming \\ ${ }^{2}$ ConocoPhillips \\ Presenting Author: dcarogeo@gmail.com
}

The chemistry of flowback and produced water from unconventional oil and gas wells changes over time. These chemical changes have been attributed to mixing of injected fracturing fluid with water from one or more formations and/or to mineral dissolution/precipitation. Water from five wells in the B-Bench of the Cretaceous Niobrara Formation, DenverJulesburg Basin, Colorado, USA was produced after injection of alkaline fracturing fluid and a 12 to 30 -day shut-in period; production continued for 78 to 228 days. Water samples were periodically analyzed to characterize and determine the origin of these waters and to determine potential geochemical and mineralogic changes to the reservoir. Concentrations of aqueous $\mathrm{Ca}, \mathrm{Mg}, \mathrm{Ba}, \mathrm{Sr}, \mathrm{Na}, \mathrm{Cl}$, and TDS increased as waters were produced. $\delta^{18} \mathrm{O}$ enrichment and increasing $\mathrm{Br} / \mathrm{Cl}$ ratios suggest that formation water originated from evaporated seawater and a single formation water mixed with the injected fracturing fluid; water from a second formation was not evident. The temporal evolution of aqueous $\mathrm{Ca}, \mathrm{Mg}, \mathrm{Ba}, \mathrm{Sr}, \mathrm{Na}, \mathrm{Cl}$, and TDS in flowback and produced water correlates $( \pm 5-10 \%)$ with mixing of formation water and fracturing fluid. Formation water dominated flowback fluid chemistry within a few 100s of barrels of production; water-rock interaction did not influence temporal trends of these constituents. In contrast, concentrations of aqueous $\mathrm{Fe}, \mathrm{SO}_{4}, \mathrm{~K}$, and $\mathrm{SiO}_{2}$ did not increase as the waters were produced; trends of these parameters suggest geochemical reaction of the formation water-fracturing fluid mixture with the rock. Three wells were shut in multiple times; these additional shut-in periods may have induced precipitation of a few tens of kilograms of Fe-bearing solids. Fracturing fluid began to dissolve calcite within the reservoir during early stages of production. However, depressurization and exsolution of dissolved $\mathrm{CO}_{2}$ in flowback and produced water may have produced $100 \mathrm{~s}$ of kilograms of calcite scale at near-surface conditions. We find that long-term geochemical evolution (greater than $\sim 30$ days) of flowback and produced water from the B-Bench of the Niobrara Formation was dominated by formation water. Alkaline fracturing fluid-mineral reaction in the reservoir was limited, but near-surface calcite scale may be significant. 